\title{
Inhibition of human prostate cancer (PC-3) cells and targeting of PC-3-derived prostate cancer stem cells with koenimbin, a natural dietary compound from Murraya koenigii (L) Spreng
}

This article was published in the following Dove Press journal:

Drug Design, Development and Therapy

\author{
Behnam Kamalidehghan' \\ Soudeh Ghafouri-Fard' \\ Elahe Motevaseli2,3 \\ Fatemeh Ahmadipour ${ }^{4}$ \\ 'Department of Medical Genetics, \\ School of Medicine, Shahid Beheshti \\ University of Medical Sciences, Tehran, \\ Iran; ${ }^{2}$ Department of Molecular \\ Medicine, School of Advanced \\ Technologies in Medicine, Tehran \\ University of Medical Sciences, Tehran, \\ Iran; ${ }^{3}$ Food Microbiology Research \\ Center, Tehran University of Medical \\ Sciences, Tehran, Iran; ${ }^{4}$ Department \\ of Pharmacy, Faculty of Medicine, \\ University of Malaya, Kuala Lumpur, \\ Malaysia
}

Background: Inhibition of prostate cancer stem cells (PCSCs) is an efficient curative maintenance protocol for the prevention of prostate cancer. The objectives of this study were to assess the efficiency of koenimbin, a major biologically active component of Murraya koenigii (L) Spreng, in the suppression of PC-3 cells and to target PC-3-derived cancer stem cells (CSCs) through apoptotic and CSC signaling pathways in vitro.

Materials and methods: The antiproliferative activity of koenimbin was examined using MTT, and the apoptotic detection was carried out by acridine orange/propidium iodide (AO/PI) double-staining and multiparametric high-content screening (HCS) assays. Caspase bioluminescence assay, reverse transcription polymerase chain reaction (RT-PCR), and immunoblotting were conducted to confirm the expression of apoptotic-associated proteins. Cell cycle analysis was investigated using flow cytometry. Involvement of nuclear factor-kappa B (NF- $\kappa \mathrm{B})$ was analyzed using HCS assay. Aldefluor ${ }^{\mathrm{TM}}$ and prostasphere formation examinations were used to evaluate the impact of koenimbin on PC-3 CSCs in vitro.

Results: Koenimbin remarkably inhibited cell proliferation in a dose-dependent manner. Koenimbin induced nuclear condensation, formation of apoptotic bodies, and $G_{0} / G_{1}$ phase arrest of PC-3 cells. Koenimbin triggered the activation of caspase-3/7 and caspase- 9 and the release of cytochrome $c$, decreased anti-apoptotic Bcl-2 and HSP70 proteins, increased pro-apoptotic Bax proteins, and inhibited NF- $\kappa \mathrm{B}$ translocation from the cytoplasm to the nucleus, leading to the activation of the intrinsic apoptotic pathway. Koenimbin significantly $(P<0.05)$ reduced the aldehyde dehydrogenase-positive cell population of PC-3 CSCs and the size and number of PC-3 CSCs in primary, secondary, and tertiary prostaspheres in vitro.

Conclusion: Koenimbin has chemotherapeutic potential that may be employed for future treatment through decreasing the recurrence of cancer, resulting in the improvement of cancer management strategies and patient survival.

Keywords: aldehyde dehydrogenase activity, ALDH, nuclear factor-kappa, NF-kB, prostasphere formation, CD44+/CD133+ surface markers

\section{Introduction}

Prostate cancer is the most prevalently detected malignancy and the second major risk of male mortality in Western countries. ${ }^{1}$ Prostate cancer mortality occurs due to bone and lymph node metastases and reversion from androgen-dependent to androgen-independent prostatic growth. ${ }^{2}$ The androgen-dependent stage of prostate cancer may be effectively treated with androgen deprivation therapy, resulting in involution of the prostate gland, due
Correspondence: Soudeh Ghafouri-Fard Department of Medical Genetics, School of Medicine, Shahid Beheshti University of Medical Sciences, Daneshjou Boulevard, Tehran 19839-63| I3, Iran

Email s.ghafourifard@sbmu.ac.ir (c) (1) (5) 2018 Kamalidehghan et al. This work is published and licensed by Dove Medical Press Limited. The full terms of this license are available at https://www.dovepress.com/terms.php (c) $\mathrm{BY}$ and incorporate the Creative Commons Attribution - Non Commercial (unported, v3.0) License (http://creativecommons.org/licenses/by-nc/3.0/). By accessing the work you hereby accept the Terms. Non-commercial uses of the work are permitted without any further permission from Dove Medical Press Limited, provided the work is properly attributed. For permission for commercial use of this work, please see paragraphs 4.2 and 5 of our Terms (https://www.dovepress.com/terms.php). 
to suppression of cellular proliferation and apoptotic stimulation. ${ }^{3}$ However, in the majority of patients, transformation to the mortal stage of androgen independence, for which there is no effectual life-extending treatment, eventually occurs. ${ }^{4,5}$ Therefore, intense investigations are required to better understand the androgen-independent impairment and identification of the most effective therapeutic approach toward prostate cancer.

Medicinal plants are deemed as a promising source of bioactive agents for cancer treatment. ${ }^{6}$ In this regard, Murraya koenigii (L) Spreng, renowned as Surabhinimba in Sanskrit and locally as the curry leaf, is a member of the Rutaceae family and is widely found in South Asia. ${ }^{7}$ The leaves of M. koenigii are utilized in foods as a seasoning material. ${ }^{7}$ Different parts of $M$. koenigii are used for the treatment of chronic fever, dysentery, dyspepsia, nausea, dropsy, mental impairment, diabetes, and diarrhea. ${ }^{7-9}$ Different carbazole alkaloids with considerable biological activities and properties have been extracted from M. koenigii. $^{7}$

Apoptosis and cell cycle arrest are vital mechanisms associated with the suppression of cell proliferation using several chemotherapeutic agents. ${ }^{7,10,11}$ In addition, constitutive stimulation of nuclear factor-kappa $\mathrm{B}(\mathrm{NF}-\kappa \mathrm{B})$ is common in different human cancers, including prostate cancer, leading to the upregulation of proteins encoding adhesion molecules, inflammatory cytokines, growth factors, and anti-apoptotic proteins. ${ }^{12}$ Accordingly, the inhibition of the NF- $\kappa B$ signaling pathway is an important chemotherapeutic objective. ${ }^{7,13}$

Many different human cancer cell lines reflecting the characteristics of cancer tissues have been established for biological and genetic studies, chemoresistance, and drug therapeutic approaches. ${ }^{14} \mathrm{~A}$ more recent approach in the treatment of cancer is the targeting of cancer stem cells (CSCs), which is accountable for the development of chemoresistance as reported in previous scientific evidences. ${ }^{7,15,16}$ The concept of CSCs states that only some cells from the heterogeneous malignant cells within the tumor itself have the capability to induce cancer. ${ }^{17}$ The population of these malignant cells is called CSCs due to their stem cell-like characteristics of self-renewal, differentiation, and tissue genesis. ${ }^{18}$ The specific aim of the CSC concept is the advancement of CSC-targeting treatments that would substantially improve recent cancer therapies. ${ }^{19,20}$

The PC-3 cell is considered as a classical prostate cancer cell line. It is used as a model of androgen-independent prostate cancer. $^{21,22}$ This cell line has high metastatic potential compared to other prostate cancer cell line models. ${ }^{23,24}$ Therefore, the current study is aimed at investigating the anticancer effect of koenimbin against PC-3 cells and PC-3-derived prostate CSCs (PCSCs) and its potential to induce the extrinsic and/or intrinsic apoptotic signaling pathways and inhibition of prostasphere formation of PC-3 CSCs.

\section{Materials and methods Materials}

In this study, koenimbin was extracted from the leaves of M. koenigii with a purity of $98.5 \%$, which was obtained as a generous gift from Prof Aspollah Sukari, Faculty of Science, University Putra Malaysia (UPM). The chemical and physical features of koenimbin (Figure 1) were consistent with those of previous studies. ${ }^{7,25}$

\section{Cell cultures}

RWPE-1 cells (normal human prostate cells) and human PC-3 cells from the American Type Culture Collection (ATCC, Manassas, VA, USA) were obtained as a gift from Dr Yeap Swee Keong at the Institute of Bioscience (IBS), UPM. The PC-3 cells were cultured in RPMI-1640 medium supplemented with $10 \%$ fetal bovine serum (FBS), streptomycin $(100 \mathrm{Ig} / \mathrm{mL})$ (Gibco BRL; Thermo Fisher Scientific, Waltham, MA, USA), and penicillin (100 IU/mL). The RWPE-1 cells were cultured in keratinocyte serum-free medium (K-SFM kit) supplemented with $0.2 \mathrm{ng} / \mathrm{mL}$ of epidermal growth factor and $25 \mu \mathrm{g} / \mathrm{mL}$ of bovine pituitary extract. The cells in the exponential growth phase with approximately $70 \%-80 \%$ confluency were cultured for experimental purpose in a humidified atmosphere using a $5 \% \mathrm{CO}_{2}$ incubator at $37^{\circ} \mathrm{C}$. The cultured cells were screened for Mycoplasma species using GenProb detection kit (Gen-Probe, San Diego, CA, USA) according to the manufacturer's instructions.

\section{Cell viability assay of koenimbin-induced PC-3 cells}

Cell viability of the koenimbin-induced PC-3 cells was assessed using MTT assay. Approximately $1 \times 10^{5}$ PC-3 and RWPE-1 cells/mL were seeded in a 96-well plate and incubated for $24 \mathrm{~h}$ at $37^{\circ} \mathrm{C}$ with $5 \% \mathrm{CO}_{2}$ saturation. The next day, a serial dilution of koenimbin was applied to the

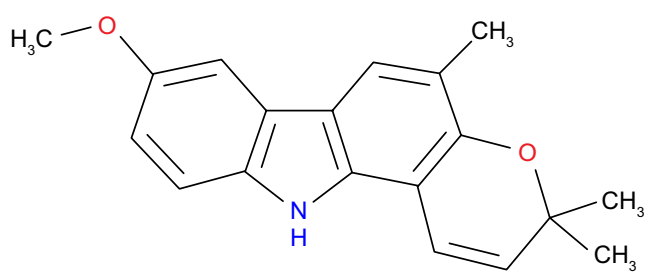

Figure I Structure of the natural alkaloid compound koenimbin $\left(\mathrm{C}_{19} \mathrm{H}_{19} \mathrm{NO}_{2}\right)$. 
PC-3 and RWPE-1 cells and incubated for 24, 48, and $72 \mathrm{~h}$, and then $20 \mu \mathrm{L}$ of 3-(4, 5-dimethylthiazol-2-yl)-2, 5-diphenyltetrazolium bromide (MTT solution, $5 \mathrm{mg} / \mathrm{mL}$ ) was added to the koenimbin-treated PC-3 and RWPE-1 cells in a dark place and covered with aluminum foil for $4 \mathrm{~h}$. After that, the media was discarded and $100 \mu \mathrm{L}$ volume of dimethyl sulfoxide (DMSO) was added into each well until the purple formazan crystals dissolved. The plate was read using a microplate reader at an absorbance of $570 \mathrm{~nm}$. The experiment was performed in triplicate $(n=3)$ to determine the antiproliferative effect of the $\mathrm{IC}_{50}$ of koenimbin against the PC-3 and RWPE-1 cells.

\section{Isolation of PCSCs}

Candidate PC-3 CSCs with the expression of CD44+/ CD133+ cell surface markers as tumor-initiating population ${ }^{26}$ were derived from PC-3 cells using a catcher tube-based cell sorter with flow cytometer (FACSCalibur ${ }^{\mathrm{TM}}$; BD Biosciences, San Jose, CA, USA). The cells were stained with $20 \mu \mathrm{L}$ of the CD44 antibody and $20 \mu \mathrm{L}$ of the CD133 antibody (CD44 mouse antihuman monoclonal antibody, fluorescein isothiocyanate [FITC] conjugate, CD133 mouse antihuman monoclonal antibody, phycoerythrin conjugate, mouse immunoglobulin G2b [FITC], mouse immunoglobulin G1 [R-phycoerythrin], all sourced from BD Biosciences) in a $5 \mathrm{~mL}$ tube at a concentration of $10^{7}$ cells $/ \mathrm{mL}$. The tubes were incubated in a dark place for $45 \mathrm{~min}$. The CD44+/CD133+ cell population was identified by quadrant analysis using BD CellQuest Pro software.

\section{Nonadherent prostasphere formation assay}

PCSCs derived from PC-3 cells were seeded in six-well ultralow attachment plates (TPP; Thermo Fisher Scientific) with a density of 1,000 cells $/ \mathrm{mL}$ of culture medium. ${ }^{20}$ The cells have the capability to grow and form spheres in serum-free DMEM/ F12 media (Lonza, USA) supplemented with $0.2 \mathrm{ng} / \mathrm{mL}$ of epidermal growth factor and $25 \mu \mathrm{g} / \mathrm{mL}$ of bovine pituitary extract. In addition, B27 (Thermo Fisher Scientific), $20 \mathrm{ng} / \mathrm{mL}$ epidermal growth factors (Thermo Fisher Scientific), and $20 \mathrm{ng} / \mathrm{mL}$ basic fibroblast growth factors (Thermo Fisher Scientific) were added to the cell culture media. Fresh medium was added every 2 days to each well. The primary cultures of PC-3 CSCs were incubated with koenimbin at various concentrations of $0,2,4,8$, and $10 \mu \mathrm{g} / \mathrm{mL}$ for prostasphere formation. The treated primary PC-3 CSCs were then subcultured to secondary and tertiary passages for each group. After 5-7 days, the number and size of the prostaspheres were compared to the control cells and images were acquired with MetaMorph 7.6.0.0 using the Eclipse TE2000-S microscope (Nikon Corporation, Tokyo, Japan).

\section{Aldefluor enzymatic assay}

A prostate cell population with high aldehyde dehydrogenase (ALDH) activity was previously examined for the enrichment of breast stem/progenitor cells. ${ }^{7}$ An Aldefluor ${ }^{\mathrm{TM}}$ enzymatic assay (StemCell Technologies, Herndon, VA, USA) was performed according to the manufacturer's instructions. Briefly, separated PC-3 CSCs derived from PC-3 cells were incubated for $40 \mathrm{~min}$ at $37^{\circ} \mathrm{C}$ in $5 \% \mathrm{CO}_{2}$, and the results were then obtained using a flow cytometer.

\section{Acridine orange (AO)/propidium iodide (PI) staining and ultramorphological assessment of apoptosis}

Human PC-3 cells were examined using AO and PI with standard procedure, ${ }^{27}$ and the results were analyzed under fluorescence microscopy (Leica attached with Q-Floro Software; Leica Microsystems, Wetzlar, Germany). Briefly, approximately $1 \times 10^{5} \mathrm{PC}-3$ cells $/ \mathrm{mL}$ were seeded in a small $25 \mathrm{~mL}$ culture flask and then treated with $6 \mu \mathrm{g} / \mathrm{mL}$ of koenimbin for $48 \mathrm{~h}$. After that, the PC-3 cells were collected and spun down at $200 \mathrm{~g}$ for $5 \mathrm{~min}$ to remove the medium. Prior to staining with $\mathrm{AO} / \mathrm{PI}$, the PC-3 cells were washed twice with cool phosphate-buffered saline (PBS). Then, equal amounts of fresh $\mathrm{AO} / \mathrm{PI}(10 \mu \mathrm{g} / \mathrm{mL})$ were prepared and added to the cells on a glass slide using a cover slip. About $30 \mathrm{~min}$ prior to the fluorescence fading, the slides were observed using fluorescence microscopy.

\section{Bioluminescence assay of caspase- $3 / 7$, caspase-8, and caspase-9}

The activities of different caspases including 3/7/8/9 were determined according to the manufacturer's guidelines. Briefly, approximately $1 \times 10^{5} \mathrm{PC}-3$ cells $/ \mathrm{mL}$ were seeded overnight in a white 96-well microplate and then treated with different concentrations of koenimbin for $24 \mathrm{~h}$. After that, an equal volume of caspase-3/7/8/9-Glo reagents was used according to the manufacturer's instructions. The results were then obtained using a Tecan Infinite ${ }^{\circledR} 200$ Pro (Tecan, Männedorf, Switzerland) microplate reader through the calculation of luminescence signals.

\section{Cell cycle analysis}

The PC-3 cells were plated and incubated overnight at $37^{\circ} \mathrm{C}$ with $5 \% \mathrm{CO}_{2}$ and then treated with different concentrations of 
koenimbin for $24 \mathrm{~h}$. The PC-3 cells were harvested and stained with a BD cycletest Plus DNA reagent kit (BD Biosciences) according to the manufacturer's protocols and subjected to cell cycle analysis using Guava easyCyte 8HT benchtop flow cytometer (Merck \& Co., Inc., Whitehouse Station, NJ, USA).

\section{Nuclear morphology, membrane permeability, mitochondrial membrane potential (MMP), and cytochrome $c$ release analysis}

Approximately $1 \times 10^{5} \mathrm{PC}-3$ cells/mL were plated in a 96-well plate (Genetix USA Inc, San Jose, CA, USA) and incubated for $24 \mathrm{~h}$ at $37^{\circ} \mathrm{C}$ with $5 \% \mathrm{CO}_{2}$. The PC-3 cells were then exposed to $6 \mu \mathrm{g} / \mathrm{mL}$ koenimbin for $48 \mathrm{~h}$. A Cellomics Multiparameter Cytotoxicity 3 Kit (Cellomics, Pittsburgh, PA, USA) was employed for the identification of nuclear morphology, membrane permeability, MMP, and cytochrome $c$ release. ${ }^{28} \mathrm{MMP}$ dye and the cell permeability dye were used to determine live cells and incubated for $1 \mathrm{~h}$. After that, the nucleus was stained using Hoechst 33258 dye. The cells were then analyzed using Cellomics ArrayScan high-content screening (HCS) reader (Cellomics, Pittsburgh, PA, USA).

\section{RNA extraction and cDNA synthesis of $\mathrm{Bcl}-2, \mathrm{Bax}$, and HSP70}

RNA from the control cells and PC-3 cells induced with koenimbin concentrations of 4 and $6 \mu \mathrm{g} / \mathrm{mL}$ for $48 \mathrm{~h}$ was extracted using RNeasy Mini Kit (Qiagen NV, Venlo, the Netherlands) according to the manufacturer's instructions. After that, $1 \mu \mathrm{g}$ of RNA was then subjected to cDNA synthesis using the QuantiTect Reverse Transcription Kit (Qiagen NV). Approximately $1 \mu \mathrm{g}$ of cDNA was used for polymerase chain reaction (PCR) amplification using specific primers for the $B a x, B c l-2$, and $H S P 70$ genes. $\beta$-Actin mRNA was employed as the loading internal control.

The primers for Bax are sense, 5'-TTT GCT TCA GGG TTT CAT CC-3', and antisense, 5'-GCC ACT CGG AAA AAG ACC TC-3'; the primers for Bcl-2 are sense, $5^{\prime}$-ATG AAC TCT TCC GGG ATG G-3', and antisense, 5'-TGG ATC CAA GGC TCT AGG TG-3'; the primers for HSP70 are sense, 5'-CGC AGC TGA ACA AGC TAA ACA ATC-3', and antisense, 5'-GAT TGT TTA GCT TGT TCA GCT GCG-3'; and the primers for $\beta$-actin are sense, 5'-CGG GAA ATC GTG CGT GAC-3', and antisense, 5'-GCC TAG AAG CAT TTG CGG TG-3'. PCR amplification was carried out using a thermal cycle, and the reaction was initiated with preliminary denaturation at $95^{\circ} \mathrm{C}$ for $5 \mathrm{~min}$, followed by 30 cycles of denaturation, annealing, and extension at $95^{\circ} \mathrm{C}$ for $30 \mathrm{~s}$, $60^{\circ} \mathrm{C}$ for $40 \mathrm{~s}$, and $72^{\circ} \mathrm{C}$ for $1 \mathrm{~min}$, respectively. The reaction was completed after final extension at $72^{\circ} \mathrm{C}$ for $10 \mathrm{~min}$. The amplification product sizes of $\mathrm{Bax}, \mathrm{Bcl}-2$, and $\beta$-actin were 213,166 , and $515 \mathrm{bp}$, respectively. The PCR products were exposed to $1.5 \%$ agarose gel electrophoresis, then stained, and visualized under ultraviolet (UV) light using Gel Doc XR System (Bio-Rad Laboratories Inc., Hercules, CA, USA).

\section{Human apoptotic protein profiler array}

PC-3 cells induced with $6 \mu \mathrm{g} / \mathrm{mL}$ of koenimbin for $48 \mathrm{~h}$ were compared to the control untreated PC-3 cells to determine the apoptotic-associated proteins using a proteome profiler array (human apoptosis antibody array kit; RayBiotech, Norcross, GA, USA), according to the manufacturer's instructions. Briefly, $250 \mu \mathrm{g}$ of extracted protein from each sample was incubated with antibody array membrane and was then quantified using a Biospectrum AC ChemiHR 40 system (UVP, Upland, CA, USA). The membrane was analyzed using online ImageJ analysis software.

\section{Western blot analysis}

The koenimbin-induced PC-3 cells with different concentrations of 4,8 , and $16 \mu \mathrm{g} / \mathrm{mL}$ were cultured in a small $25 \mathrm{~mL}$ flask (TPP Brand, Trasadingen, Switzerland). Briefly, the PC-3 cells were collected, washed with PBS, centrifuged, and mixed with lysis buffer (50 mM Tris-HCL pH 8.0, $120 \mathrm{mM} \mathrm{NaCl}, 0.5 \% \mathrm{NP}-40,1 \mathrm{mM}$ phenylmethanesulfonyl fluoride) to extract the proteins from the control and treated PC-3 cells. Approximately $40 \mu \mathrm{g}$ of extracted proteins was separated using $12 \%$ sodium dodecyl sulfate polyacrylamide gel electrophoresis (SDS-PAGE) and then moved to the polyvinylidene difluoride (PVDF) membrane (Bio-Rad Laboratories Inc.), and PVDF membrane was blocked with 5\% nonfat milk mixed with Tris-buffered Saline (TBS)-Tween buffer (0.12 M Tris-base, 1.5 M NaCl, 0.1\% Tween 20) for $30 \mathrm{~min}$ at room temperature. The membranes were then incubated with the appropriate primary antibodies (Bax, Bcl-2, HSP70, and $\beta$-actin) overnight at $4{ }^{\circ} \mathrm{C}$. After that, the membranes were washed with TBS-Tween buffer, incubated with alkaline phosphatase-conjugated goat anti-mouse or goat anti-rabbit secondary antibodies for $30 \mathrm{~min}$ at room temperature, and then washed with TBST buffer. The primary antibodies such as $\beta$-actin (sc-130300), Bax (sc-20067), HSP70 (sc-69705), NF-кB/P65 (sc-398442), were purchased from Santa Cruz Biotechnology Inc. (Dallas, TX, USA), while Bcl-2 (ab38629) was purchased from Abcam, Cambridge, UK. After washing three times with TBST, the PVDF membranes were incubated for $20 \mathrm{~min}$ at room temperature with 
5-bromo-4-chloro-3-indolyl phosphate/nitro blue tetrazolium (Santa Cruz Biotechnology Inc.) for sensitive colorimetric detection to quantify the target protein bands.

\section{Statistical analysis}

In this study, statistical analysis was calculated using Statistical Package for Social Sciences version 16.0 (SPSS Inc., Chicago, IL, USA) software. The experiments are reported as mean \pm SD of three independent experiments. Normality and homogeneity of variance assumptions were tested. A $P$-value of $<0.05$ is statistically significant.

\section{Results}

\section{MTT cell viability assay}

The effect of koenimbin on PC-3 and RWPE-1 cells was evaluated using MTT method (Figure 2; Table 1). The $\mathrm{IC}_{50}$ rates were $8.78 \pm 0.15,6.2 \pm 0.61$, and $3.73 \pm 0.23 \mu \mathrm{g} / \mathrm{mL}$ for koenimbininduced PC-3 cells during 24, 48, and 72 h, respectively.

\section{Isolation of CD44+/CDI33+ surface markers of PCSCs}

In this study, the CD44+/CD133+ surface markers of PCSCs were first isolated from PC-3 cells using cell sorting based on $\mathrm{CD} 44+/ \mathrm{CD} 133+$ surface marker expression and were then cultured in prostasphere formation conditions. PCSCs derived from PC-3 cells were identified by the expression of CD44 and CD133 cell surface markers (Figure 3A and B).

\section{Inhibitory effect of koenimbin on prostasphere formation}

Prostasphere formation culture was carried out in serum-free media. The number of prostaspheres was calculated under a Nikon Eclipse TE2000-S microscope (Nikon, Japan), and images were then interpreted using MetaMorph 7.6.0.0. It has been demonstrated that prostate stem/progenitor cells enrich prostaspheres as nonadherent spherical clusters of cells. ${ }^{34}$ Therefore, PC-3 CSCs were exposed to different concentrations of koenimbin to evaluate whether koenimbin has the capability to inhibit prostasphere formation in vitro. According to our results, koenimbin suppressed the nonadherent spherical clusters of PCSCs in vitro, in which these cells were not able to generate secondary spheres and differentiate along multiple lineages. As shown in Figure 4A and B, koenimbin significantly $(P<0.01)$ suppressed prostasphere formation with increasing concentrations of koenimbin (Figure 4A and B).

\section{Inhibitory effect of koenimbin in an ALDH-positive cell population}

The PC-3 cell population with high ALDH activity (Figure 5A and $\mathrm{B}$ ) as determined using the Aldefluor assay demonstrated

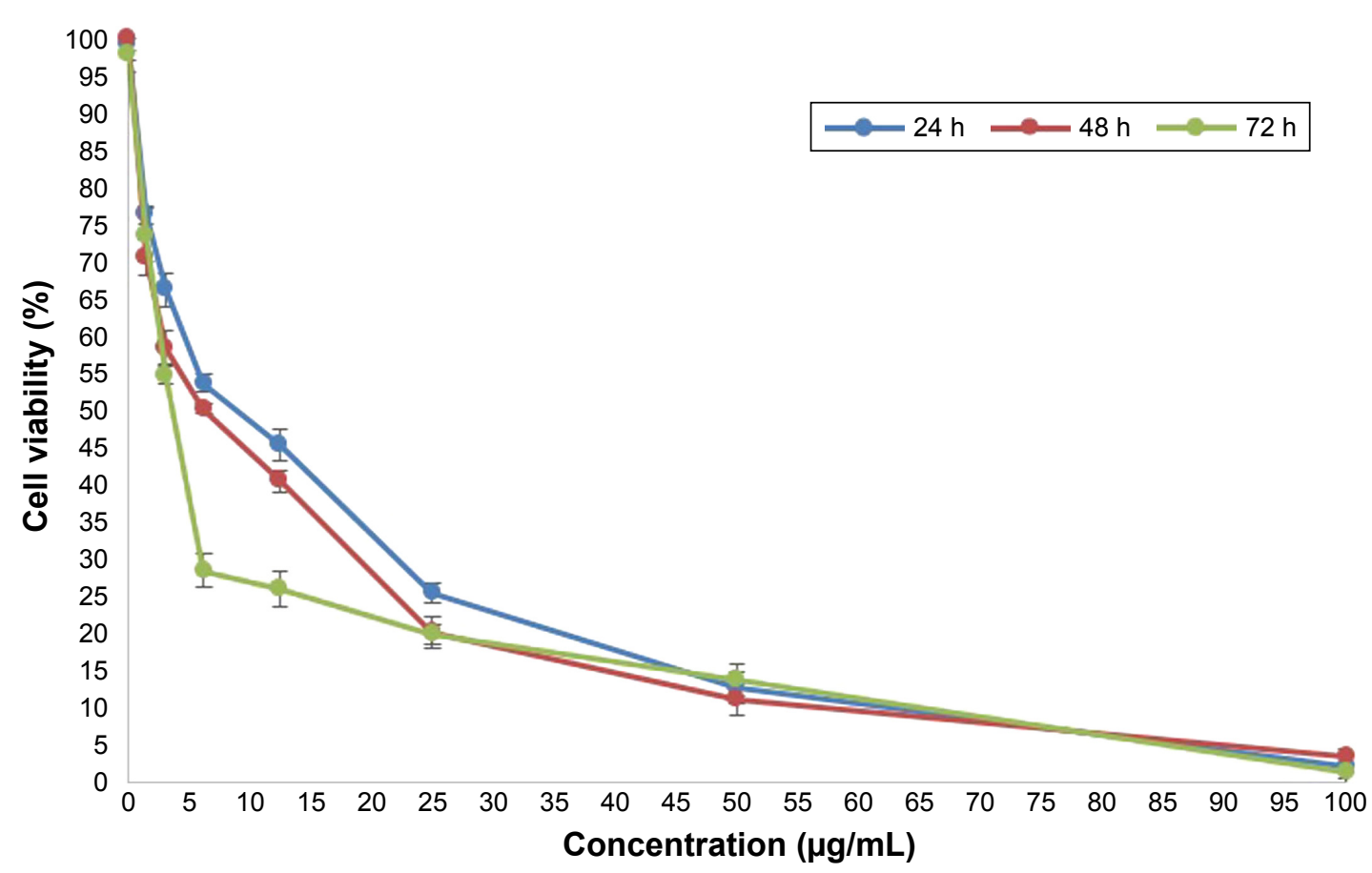

Figure 2 MTT cell viability assay of koenimbin-induced PC-3 at 24, 48, and $72 \mathrm{~h}$.

Note: Data are indicated as mean \pm SD $(n=3)$.

Abbreviation: MTT, 3-(4,5-dimethylthiazol-2-yl)-2,5-diphenyltetrazolium bromide. 
Table I The $\mathrm{IC}_{50}$ rates of koenimbin-induced PC-3 and RWPE-I cells

\begin{tabular}{llll}
\hline Cell line & \multicolumn{3}{l}{$\mathbf{I C}_{50} \pm \mathbf{S D}(\mu \mathrm{g} / \mathbf{m L})$} \\
\cline { 2 - 4 } & $\mathbf{2 4 \mathbf { h }}$ & $\mathbf{4 8 ~ h}$ & $\mathbf{7 2 ~ \mathbf { ~ }}$ \\
\hline PC-3 (prostate cancer cell line) & $8.78 \pm 0.15$ & $6.2 \pm 0.6 \mathrm{I}$ & $3.73 \pm 0.23$ \\
RWPE-I (normal human & $21 \pm 0.43$ & $18 \pm 0.89$ & $12 \pm 0.67$ \\
prostate cell line) & & & \\
\hline
\end{tabular}

Note: Results are shown as mean \pm SD of three independent experiments $(n=3)$.

enriched prostate stem/progenitor cells and increased self-renewal of PC-3 CSCs. As shown in Figure 5C, koenimbin with concentrations of $2,4,8$ and $10 \mu \mathrm{g} / \mathrm{mL}$ significantly $(P>0.01)$ decreased the ALDH-positive population of PC-3 CSCs by approximately $20 \%, 33 \%, 53 \%$, and $70 \%$, respectively. This result demonstrates that koenimbin effectively reduced the PC-3 CSC population in vitro. In this study, koenimbin has the capability to suppress PC-3 CSCs at concentrations of 4,8 , and $10 \mu \mathrm{g} / \mathrm{mL}$, hardly affecting the RWPE-1 cell population, revealing that koenimbin may preferentially have potential properties to target PC-3 CSCs.

\section{Quantification of apoptotic cells using $\mathrm{AO} / \mathrm{PI}$}

Approximately 200 cell populations of PC-3 cells were randomly and differentially scored for viable, necrotic, early, and late apoptotic events using fluorescence microscopy. Our study indicated that koenimbin has the capability to trigger the morphological characteristics that are associated with apoptotic events. The viable untreated PC-3 cells were observed to have an intact green color. However, early apoptosis was observed with bright green color due to incorporation of AO within the fragmented DNA. In addition, blebbing and nuclear changes were noticed in koenimbininduced PC-3 cells at $48 \mathrm{~h}$ post treatment. Late apoptotic events were observed as orange color due to $\mathrm{AO}$ binding to denatured DNA (Figure 6).

\section{Enzymatic caspase-3, caspase-7, caspase-8, and caspase- 9 activation assays}

The activation of caspase- 3 , caspase- 7 , caspase-8, and caspase- 9 was examined through bioluminescence assay in koenimbin-induced PC-3 cells. In this experiment, koenimbin promoted the activation of caspase-3, caspase-7, and caspase-9 in koenimbin-induced PC-3 cells. However, the koenimbin-induced PC-3 cells demonstrated a lack of remarkable stimulation associated with caspase- 8 in koenimbin-induced PC-3 cells (Figure 7). These results indicated that koenimbin has the capability to induce apoptosis in PC-3 cells through the intrinsic apoptotic signaling pathway.

\section{Cell cycle analysis}

According to the cell cycle analysis, koenimbin-induced PC-3 cells demonstrated remarkable cell cycle alterations and distributions with the increase in cell arrest in the $\mathrm{G}_{0} / \mathrm{G}_{1}$ phase. However, a reduction in cell cycle arrest was observed in the $\mathrm{S}$ and $\mathrm{G}_{2} / \mathrm{M}$ phases at a concentration of $6 \mu \mathrm{g} / \mathrm{mL}$. Hence, the cell cycle analysis revealed a significant $(P<0.05)$ inhibitory effect of koenimbin in PC-3 cells (Figure 8A-E).

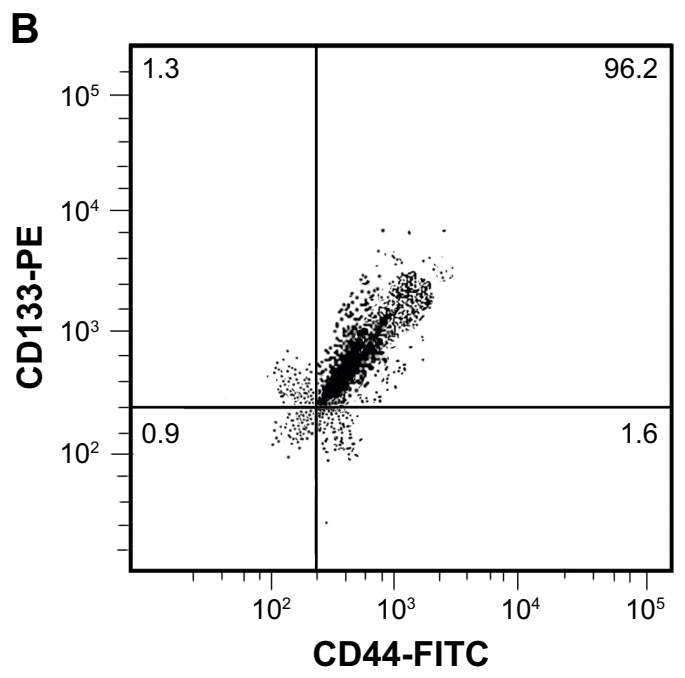

Figure 3 Surface marker CD44+/CD 133+ expressions in human PC-3 cells (A) and after isolation of PC-3-derived PCSCs (B) in quadrant analysis. Note: Each experiment was carried out three times $(n=3)$.

Abbreviations: FITC, fluorescein isothiocyanate; PCSCs, prostate cancer stem cells. 
A
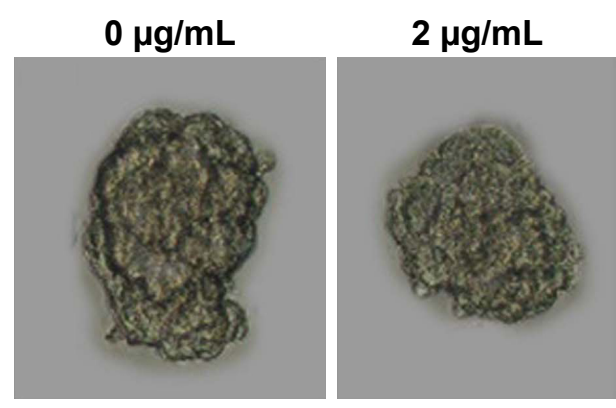

$8 \mu \mathrm{g} / \mathrm{mL}$
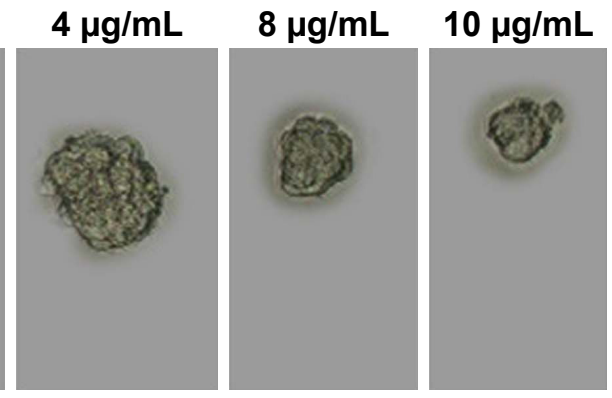

B

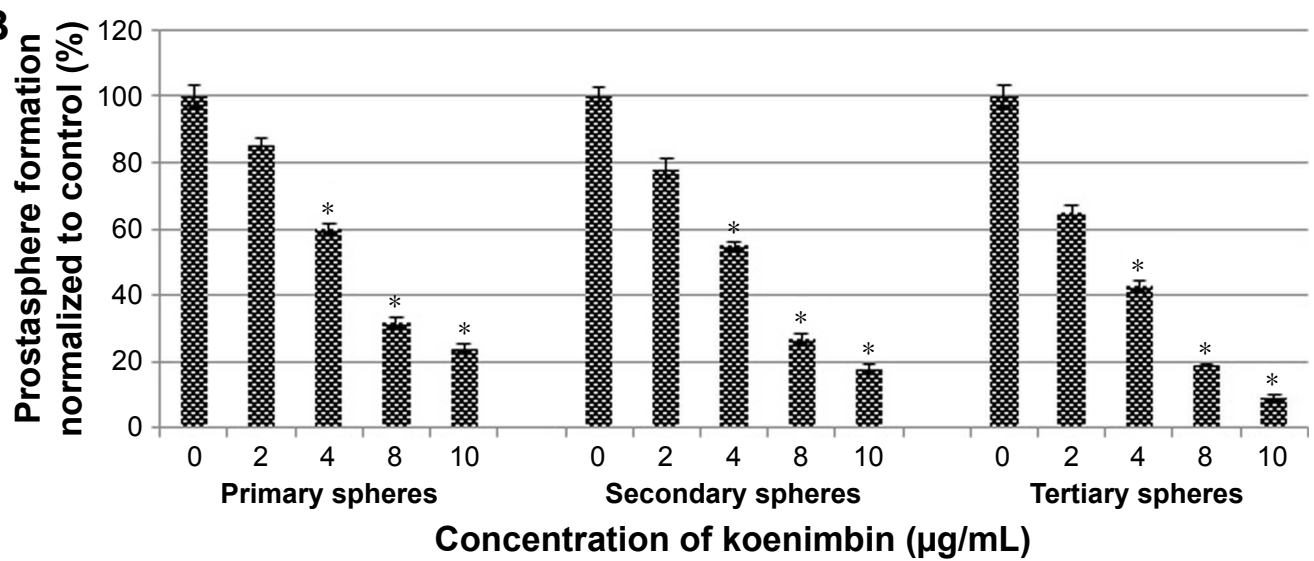

Figure 4 Prostasphere formation of PC-3 CSCs derived from PC-3 cells.

Notes: Different concentrations of koenimbin decreased the size of the primary prostasphere (A) of PC-3 CSCs (magnification, $\times 100)$. Koenimbin inhibited prostasphere formation of PC-3 CSCs and reduced the number and size of the prostasphere (B). Koenimbin treatment reduced the number and size of mammospheres. Data are mean $\pm S D(n=3)$. $* P<0.05$ vs control.

Abbreviation: CSCs, cancer stem cells.

\section{Multiparametric HCS assays}

To verify the induction of apoptosis by koenimbin, the induced cells were examined for cellular abnormalities accompanying apoptosis using HCS. The koenimbin-induced PC-3 cells indicated an increase in nuclear condensation using nuclear chromatin staining with Hoechst 33342. Membrane permeability of the koenimbin-induced PC-3 cells was increased in the cytoplasm of induced cells in comparison with the control cells. MMP was remarkably reduced in koenimbininduced PC-3 cells compared to untreated control cells. The cytochrome $c$ involved in apoptotic signaling pathway was enhanced in the cytoplasm of koenimbin-induced PC-3 cells at a concentration of $6 \mu \mathrm{g} / \mathrm{mL}$ (Figure 9). The results further demonstrated that koenimbin has the capability to inhibit proliferation of PC-3 cells through inducing the apoptotic signaling pathway.

\section{Reverse transcription PCR (RT-PCR) analysis of $\mathrm{Bax}$ and $\mathrm{Bcl}-2$ mRNA expressions}

The expression of Bax and Bcl-2 mRNA (Figure 10) was determined using RT-PCR. Gene expression of Bax was upregulated in untreated PC-3 cells and was remarkably
$(P<0.05)$ increased in the koenimbin-induced PC-3 cells. In contrast, the expression of Bcl-2 and HSP70 was significantly $(P<0.05)$ downregulated in koenimbin-induced PC-3 cells compared to untreated cells.

\section{Human apoptotic protein array}

Koenimbin-induced PC-3 cells were lysed, and the important apoptotic markers were screened using a protein array. The images represent changes in apoptotic markers between treated and untreated cells. All major markers responsible for the apoptosis signaling pathway, including Bax, Bcl-2, cytochrome $c$, and caspase- $3 / 7$ and caspase- 9 , were expressed in this in vitro model. In this study, a remarkable downregulation of HSP70, Bcl-2, and XIAP was observed, while protein expressions of Bax, cytochrome $c$, and SMAC were increased in this in vitro model. To confirm the protein array result, the expression of Bcl-2, Bax, and HSP70 in koenimbin-induced PC-3 cells was determined using Western blot analysis (Figure 11).

\section{Koenimbin inhibits TNF- $\alpha$-induced NF- $\kappa B$ nuclear translocation}

Previous reports indicated that triggering NF- $\kappa B$ nuclear translocation inhibits apoptotic signaling pathways 
A

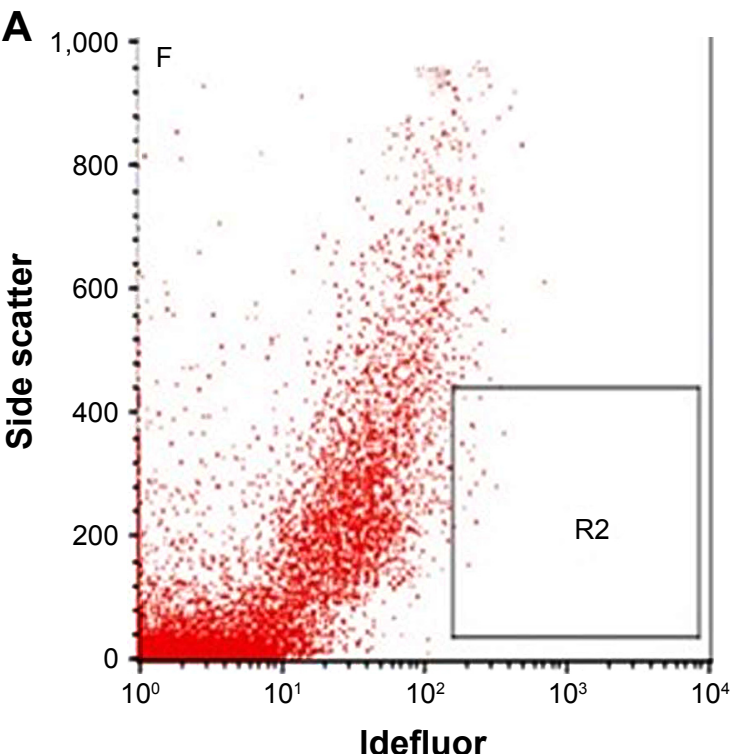

B

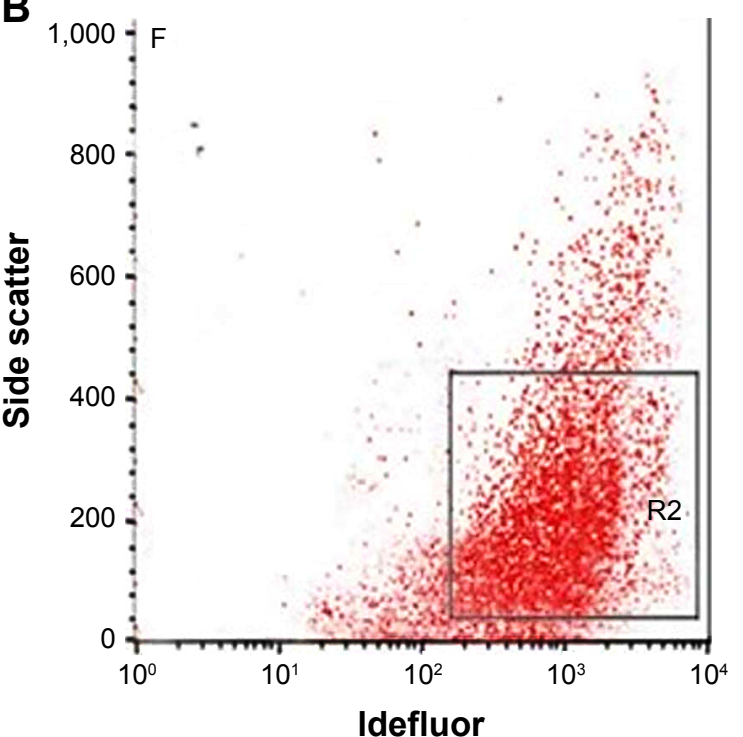

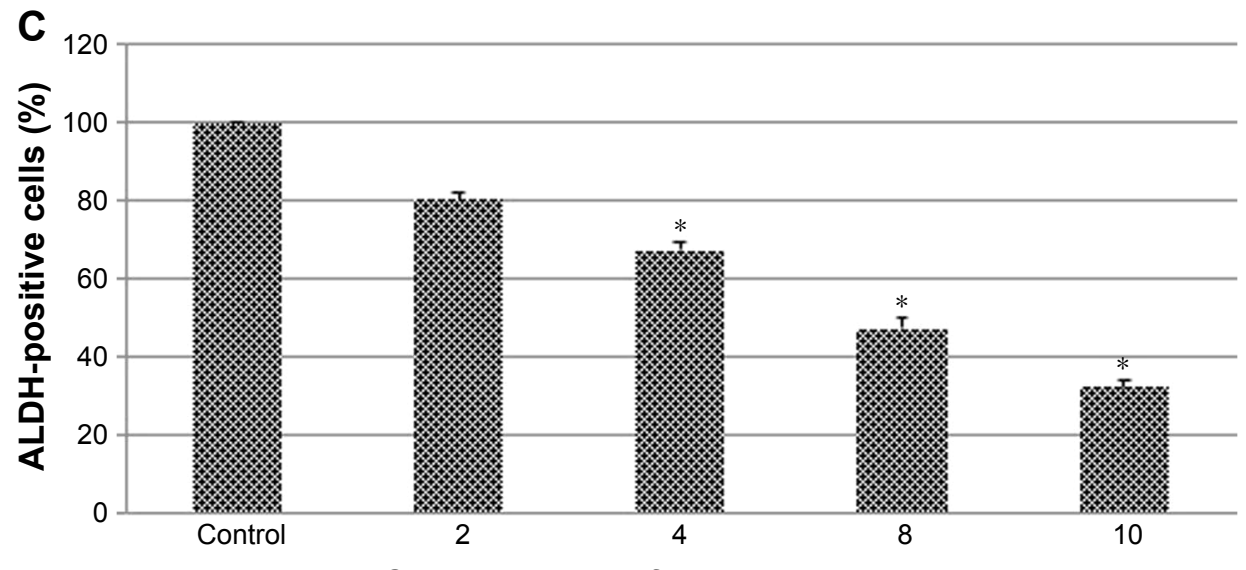

Concentration of koenimbin $(\mu \mathrm{g} / \mathrm{mL})$

Figure 5 Aldefluor assay in PC-3 cells.

Notes: Aldefluor assay of PC-3 cells prior to isolation of PC-3 CSCs (A) and after isolation of PC-3 CSCs (B). A cell population (R2) indicating high ALDH that is essential for the enrichment of PC-3 stem/progenitor cells. Representative bar chart shows the inhibitory effect of koenimbin on ALDH-positive cell population. PC-3 CSCs were induced using koenimbin at different concentrations $(\mathbf{C})$; then they were subjected to Aldefluor assay and flow cytometric analysis. Koenimbin significantly decreased the percentage of ALDH-positive cells (C). Data are mean \pm SD $(n=3)$. $* P<0.05$ vs control.

Abbreviations: ALDH, aldehyde dehydrogenase; CSCs, cancer stem cells.
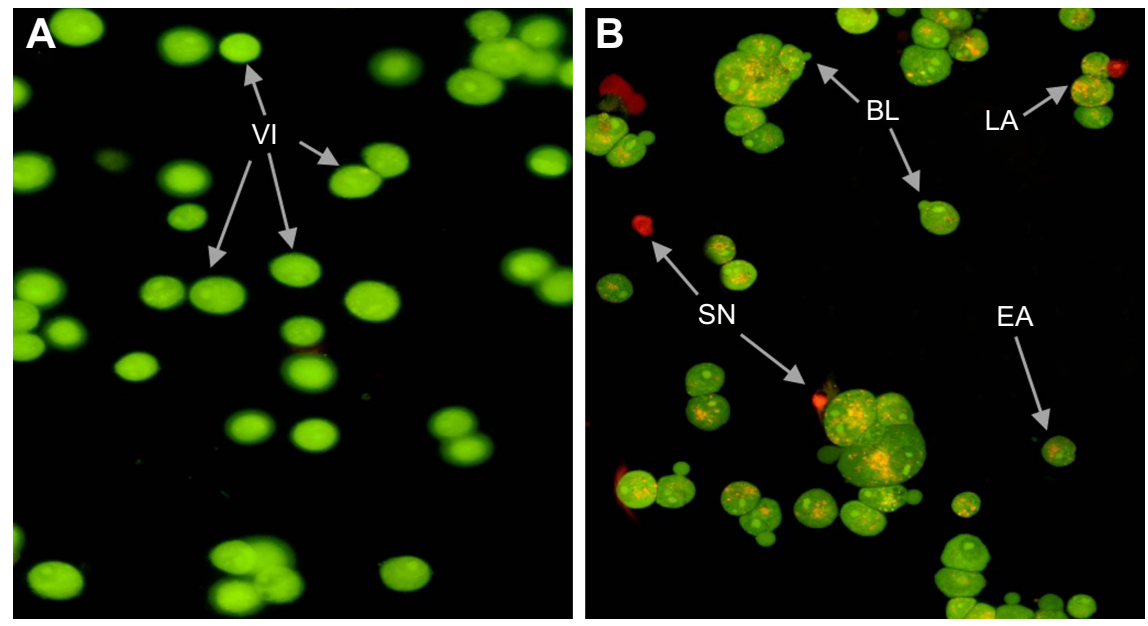

Figure 6 Fluorescent analysis using and AO/PI staining in control viable cells (A) and koenimbin-induced PC-3 cells (B) after 48 h.

Abbreviations: AO, acridine orange; BL, blebbing of cell membrane; EA, early apoptosis; LA, late apoptosis; PI, propidium iodide; SN, secondary necrosis; VI, viable cells. 


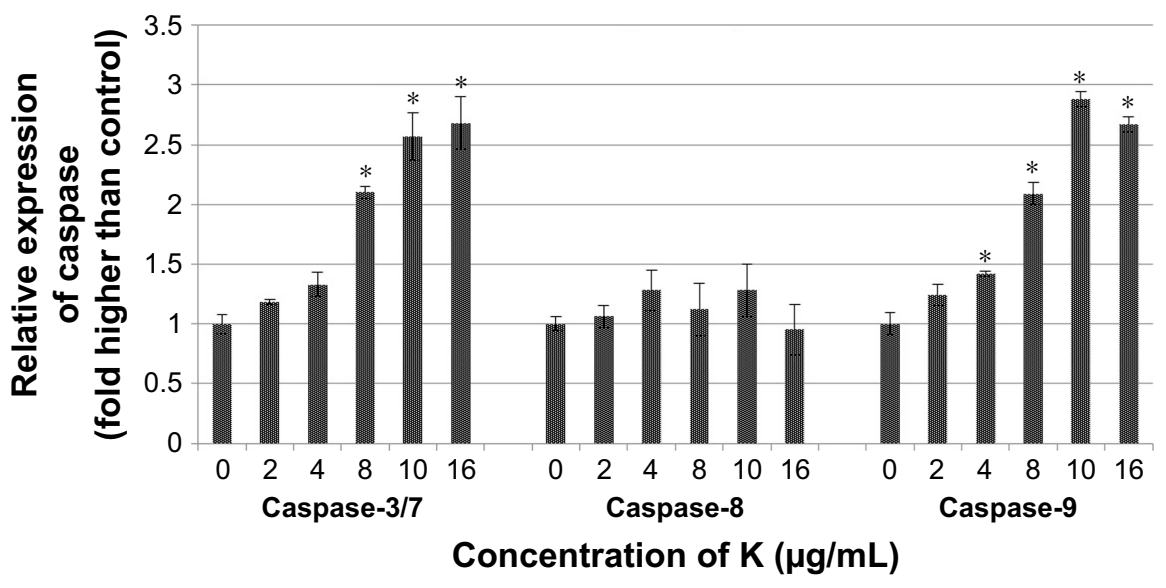

Figure 7 Relative expression of caspase-3/7, caspase-8, and caspase- 9 in koenimbin-induced PC-3 cells at different concentrations. Notes: Data are mean \pm SD $(n=3)$. $* P<0.05$ vs control. K, koenimbin.

and increases proliferation of cells. ${ }^{7}$ As indicated in Figure $12 \mathrm{~A}-\mathrm{C}$, koenimbin-induced PC-3 cells effectively decreased the NF- $\mathrm{\kappa B}$ nuclear protein at concentrations of 8 and $16 \mu \mathrm{g} / \mathrm{mL}$.

\section{Western blot analysis}

Western blot analysis on total extracted proteins from koenimbin-induced PC-3 cells confirmed the human protein array results. Bax protein expression, as a proapoptotic protein, was gradually upregulated, while HSP70 protein expression and $\mathrm{Bcl}-2$ protein expression, as antiapoptotic proteins, were gradually downregulated with increasing concentrations of koenimbin following treatment for $24 \mathrm{~h}$. $\beta$-Actin was employed as a loading control, which displayed identical intensity bands, proving equivalent protein concentration in all samples (Figure 13).

\section{Discussion}

In this study, we attempted to manifest the mechanism of action of koenimbin on human androgen-independent PC-3 cell line. The inhibition effect of koenimbin on human breast cancer cells and derived breast CSCs was investigated in our previous study. ${ }^{7}$ The koenimbin effect on human breast cancer cells was mediated through the induction of an apoptotic process via the mitochondrial pathway. ${ }^{7}$ Cell viability assays on koenimbin-induced PC-3 cells exhibited strong apoptotic induction in PC-3 cells that have been further carried out with morphological study using fluorescent microscopy AO/PI staining assay. The outcome of this study was affirmed by multiparametric cell-based HCS analysis that revealed morphological feature characteristics of apoptotic cell death, including nuclear condensation, loss of membrane symmetry, release of mitochondrial cytochrome $c$, and decrease in MMP.
Previous studies indicated that the disruption of the MMP is an early important event in apoptosis, triggering release of cytochrome $c$ and other associated apoptotic molecules from the mitochondria to the cytosol. The activation of apoptotic proteins results in the stimulation of different caspases and then leads to programmed cell death. Different studies demonstrated that the apoptotic processes can be triggered through the extrinsic pathway, where the ligand-receptor binding triggers caspase- 8 and/or via the mitochondrial pathway, in which cytochrome $c$ is moved from the mitochondria to stimulate caspase- $9 .^{7,29,30}$ The caspase- 9 stimulation results in the activation of the downstream caspase-3/7, which is accountable for the characteristics of apoptosis-associated morphological changes, including chromatin condensation, membrane blebbing, and cell shrinkage. ${ }^{31,32}$ The current study demonstrated that koenimbin-induced PC-3 cells increased the activity of caspase-3/7 and caspase-9, disrupted the MMP, and released mitochondrial cytochrome $c$ into the cytosol. These results suggest that apoptosis is mediated through the intrinsic or mitochondrial signaling pathway. Previous studies showed the role of oxidative stress in the process of apoptosis and the associated mitochondrial alterations. ${ }^{33,34}$

Bcl-2 family proteins play a fundamental role in apoptosis, and up to 14 members of the Bcl-2 family have been identified. The first category of this family is pro-apoptotic proteins including Bax, Bak, and $\mathrm{Bcl}-\mathrm{Xs}$, and the second category is antiapoptotic proteins including $\mathrm{Bcl}-2, \mathrm{Bcl}-\mathrm{XL}$, and Mcl-1. The Bcl-2 protein is located in the mitochondria, endoplasmic reticulum, and nuclear membranes, where most of the reactive oxygen species (ROS) are produced and where the free radicals realize their apoptotic influences. Bcl-2 protein plays as an antioxidant role to suppress the apoptotic process. ${ }^{35}$ However, Bax proteins, which exist in the cytosol, stimulate apoptosis by associating themselves with 

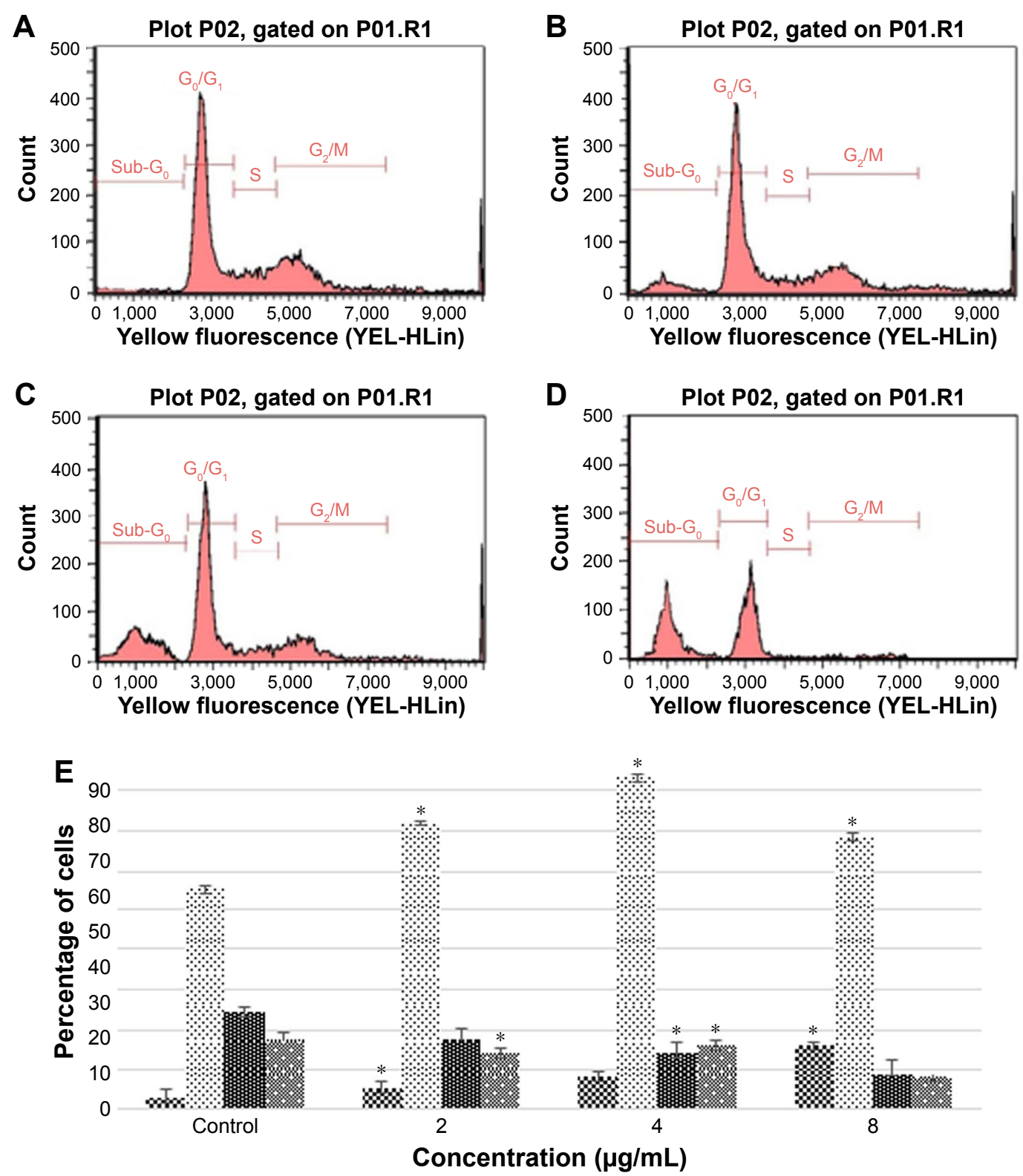

$$
\approx \mathrm{Sub}-\mathrm{G}_{0} / \mathrm{G}_{1} \quad \because \mathrm{G}_{0} / \mathrm{G}_{1} \quad \text { 明 } \mathrm{S} \approx \mathrm{G}_{2} / \mathrm{M}
$$

Figure 8 Cell cycle analysis of koenimbin-induced PC-3 cells.

Notes: Cell cycle analysis of PC-3 cells treated with $0 \mu \mathrm{g} / \mathrm{mL}$ (A), $2 \mu \mathrm{g} / \mathrm{mL}$ (B), $4 \mu \mathrm{g} / \mathrm{mL}$ (C), and $8 \mu \mathrm{g} / \mathrm{mL}$ (D) of koenimbin during $24 \mathrm{~h}$. (E) Bar graph comparison of control and koenimbin-induced PC-3 cells. The results are indicated as mean \pm SD $(n=3) * * P<0.05$.

the membrane, leading to the loss of selective mitochondrial ion permeability. ${ }^{7,36}$ The Bcl-2/Bax protein ratio plays a remarkable role in the apoptotic process. ${ }^{37} \mathrm{~A}$ study indicated that the Bcl-2 family proteins possess an important function in the regulation of mitochondrial-mediated apoptosis. It has also been stated that Bcl-2 restrains ROS-induced apoptosis, while the upregulation of pro-apoptotic Bax protein promotes ROS production. ${ }^{38}$ Consistent with previous studies on koenimbin-induced MCF-7 breast cancer cells, ${ }^{7}$ our results demonstrated that the induction of the apoptotic signaling pathway in koenimbin-induced PC-3 cells is modulated by the downregulation of Bcl-2 and HSP70 and upregulation of Bax protein expressions.

The apoptotic process is intimately associated with cell cycle arrest. ${ }^{39,40}$ It has been reported that cell cycle control is a substantial incident in the maintenance of precise cellular division. Numerous carcinogenic substances, including natural and synthetic compounds, were reported to promote chemoresistance and tumorigenesis through cell cycle dysregulation and inhibition of apoptosis in cancer cells. ${ }^{7,41,42}$ 
A
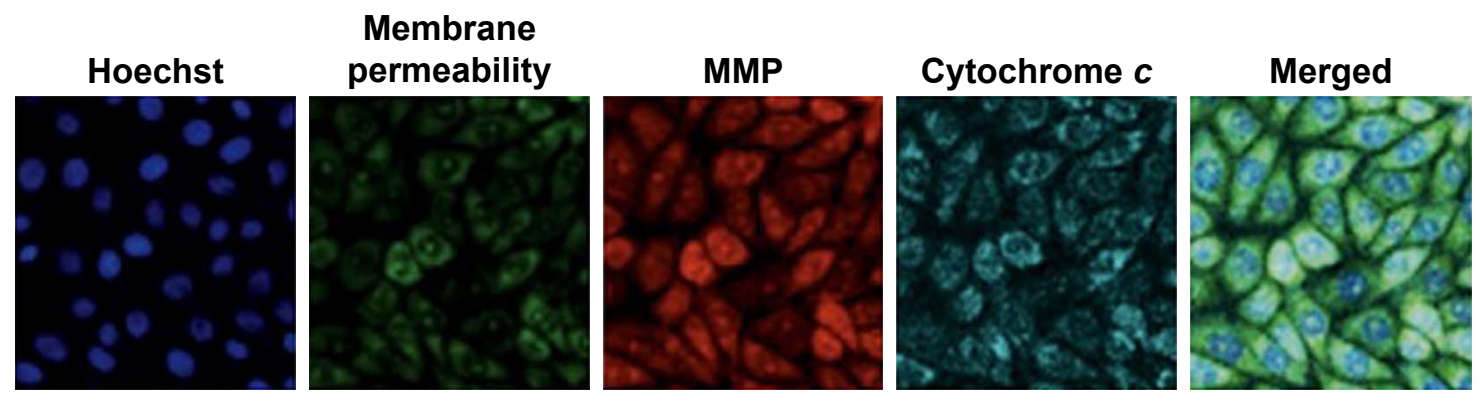

B
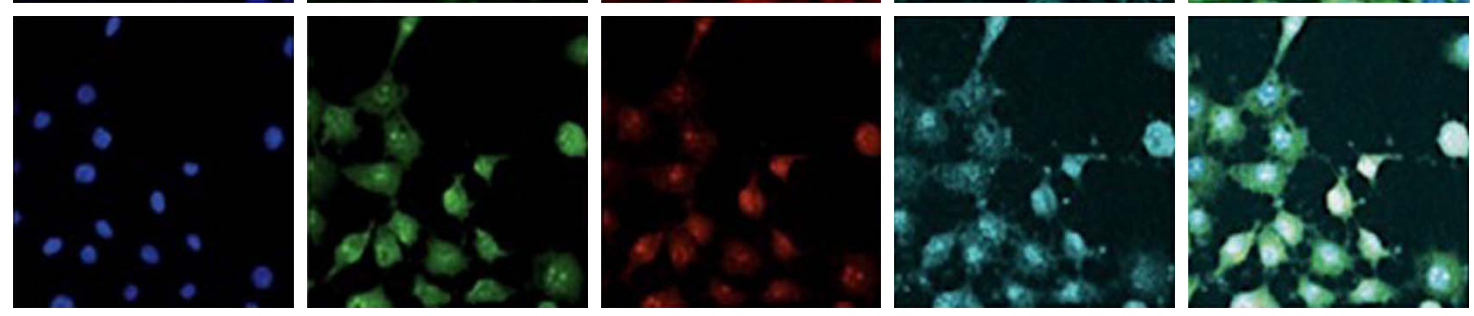

Figure 9 Representative images of PC-3 cells treated with medium alone (A) and PC-3 cells induced using koenimbin (B).

Note: The PC-3 cells are stained with Hoechst for nuclei, permeability membrane, MMP, cytochrome $c$ and merged images (magnification, $\times 20$ ).

Abbreviation: MMP, mitochondrial membrane potential.

Koenimbin-induced $\mathrm{PC}-3$ cells revealed a higher percentage of cell arrest in the $\mathrm{G}_{0} / \mathrm{G}_{1}$ phase, demonstrating the capability of koenimbin in the inhibition of cellular proliferation through $\mathrm{G}_{0} / \mathrm{G}_{1}$ phase arrest. This result is in agreement with
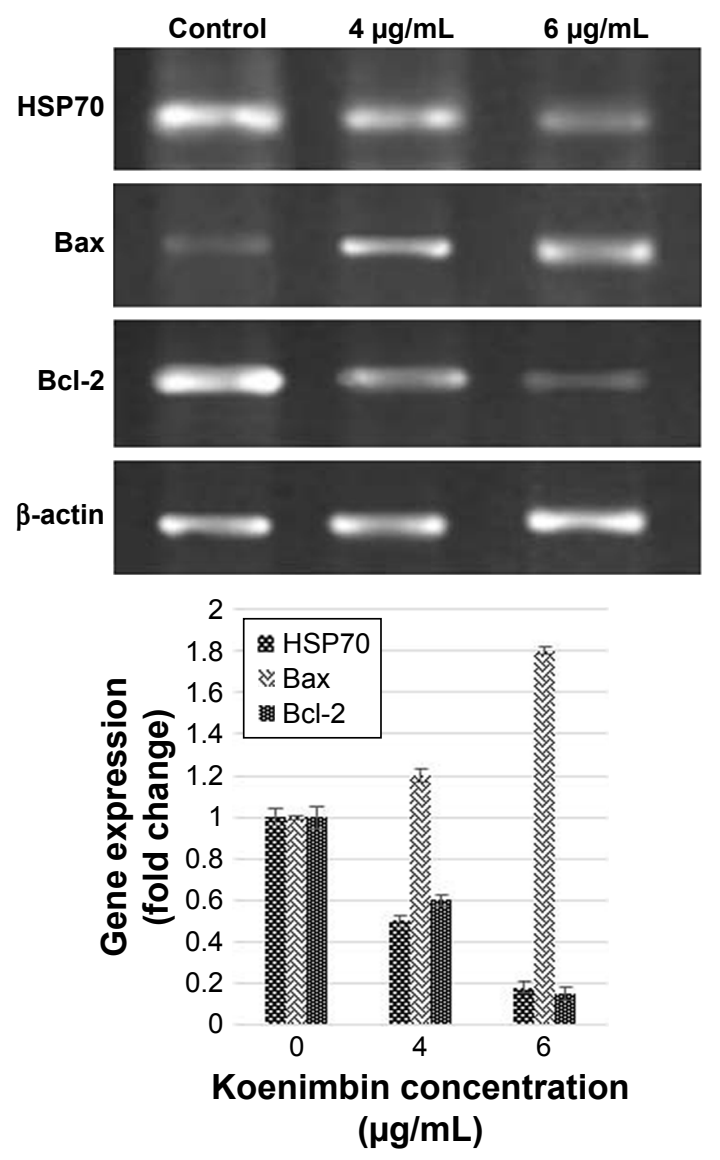

Figure $10 \mathrm{Bax}, \mathrm{Bcl}-2$, and HSP70 mRNA expression in koenimbin-induced PC-3 cells. an earlier study on the effect of koenimbin on MCF-7 breast cancer cells. $^{7}$

Many evidences have indicated that different chemotherapeutic compounds are able to stimulate the NF- $\kappa \mathrm{B}$ signaling pathway, resulting in resistance to apoptosis. ${ }^{43,44}$ Other studies reported that the stimulation of the NF- $\mathrm{BB}$ signaling pathway induces inflammation leading to tumorigenesis. ${ }^{45,46}$ In clinical investigations on prostate cancer, the upregulation of the NF- $\kappa \mathrm{B} / \mathrm{p} 65$ protein was exhibited as an independent prognosis marker in prostate cancer patients. ${ }^{31,47}$ In prostatectomy samples from prostate cancer patients with recrudesce tumor, high intensity of NF- $\mathrm{KB}$ was observed in nuclear fraction. ${ }^{31,48}$ Therefore, efficient suppression of NF- $\mathrm{KB}$ signaling pathway is an essential signaling pathway for the prevention of prostate cancer. ${ }^{49}$ In agreement with previous studies, ${ }^{7,50,51}$ we observed a remarkable translocation of cytoplasmic NF- $\kappa \mathrm{B}$ to the nuclei in koenimbin-induced PC-3 cells stimulated by TNF- $\alpha$. Our results demonstrated the effectiveness of koenimbin on TNF- $\alpha$-associated apoptosis-inducing ligands in human prostate cancer cells by interfering with the $\mathrm{NF}-\kappa \mathrm{B}$-induced antiapoptotic signaling pathway, movement of mitochondrial cytochrome $c$ into the cytosol, sequential activation of caspase-3/7/9, and high and low expression of $\mathrm{Bax}$ and Bcl-2 proteins, respectively.

Besides the NF- $\kappa \mathrm{B}$ and Bcl-2 family protein members, heat shock proteins ${ }^{28,51}$ are major inhibitors of apoptosis and maintain cell survival through the suppression of mitochondrial cytochrome $c$ release or through the inhibition of apoptosome formation. ${ }^{7}$ In the current study, Western blotting results showed a significant decrease in the expression 


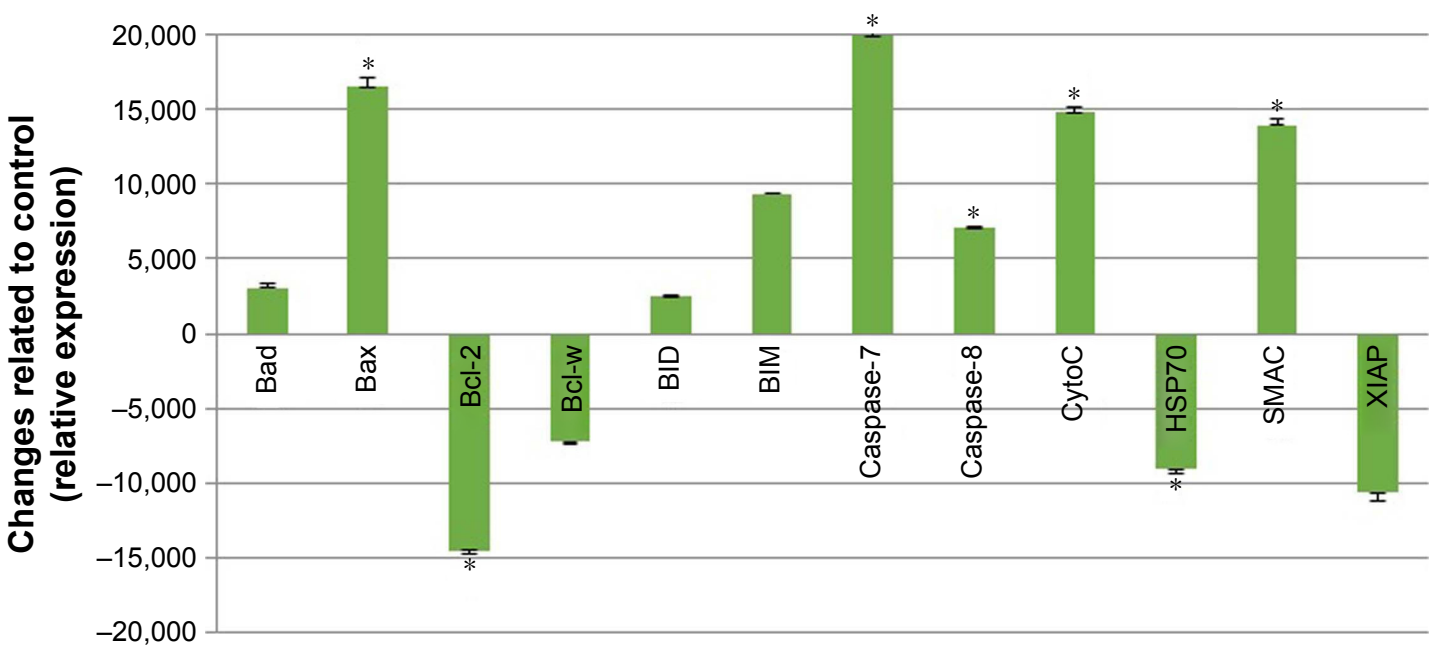

Figure II Analysis of the human apoptotic profiler array in koenimbin-induced PC-3 cells.

Notes: PC-3 cells were induced using $6 \mu \mathrm{g} / \mathrm{mL}$ of koenimbin for $48 \mathrm{~h}$. Equal amounts $(250 \mu \mathrm{g})$ of protein from each control and koenimbin-induced PC-3 cells were used for protein array. The bar chart indicates the differences between treated and control cells. Data are mean \pm SD ( $n=3)$. *A significant difference from the control $(P<0.05)$.

of HSP70 protein in koenimbin-induced PC-3 cells. This result corresponds to the outcomes of a previous report which revealed that the overexpression of HSP70 has the capability to inhibit the apoptotic process. ${ }^{7,52}$

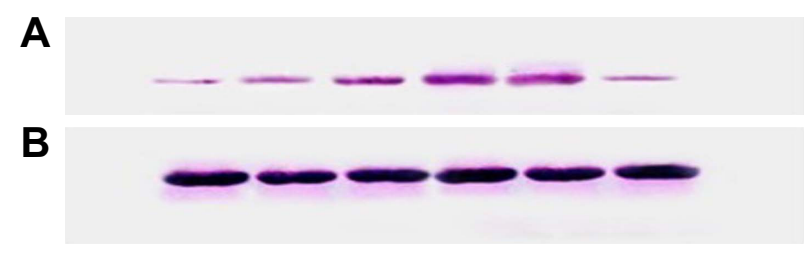

\section{C}

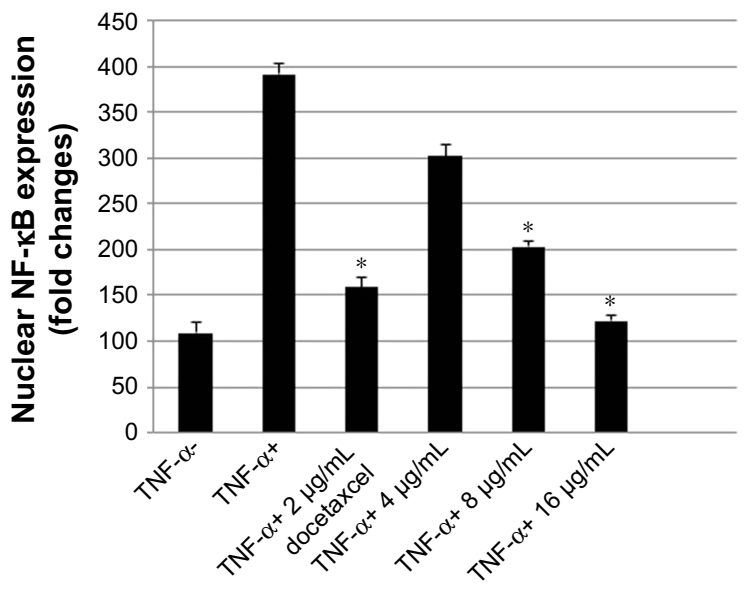

\section{Concentration $(\mu \mathrm{g} / \mathrm{mL})$}

Figure 12 Western blot analysis of NF-אB in koenimbin-treated PC-3 cells and control.

Notes: Left to right (A): TNF- $\alpha-$, TNF- $\alpha+$, TNF- $\alpha+$ docetaxel-induced PC-3 cells $(2 \mu \mathrm{g} / \mathrm{mL})$, TNF- $\alpha+$ koenimbin-treated PC-3 $(4 \mu \mathrm{g} / \mathrm{mL})$, TNF- $\alpha+$ koenimbintreated PC-3 $(8 \mu \mathrm{g} / \mathrm{mL})$, TNF- $\alpha+$ koenimbin-treated PC-3 $(16 \mu \mathrm{g} / \mathrm{mL})$, and $\beta$-actin as control (B). NF- $\mathrm{KB}$ protein expression in koenimbin-induced PC-3 cells. Representative bar chart indicates that koenimbin suppresses the TNF- $\alpha$-induced translocation of cytoplasmic NF- $\kappa B$ into the nucleus. The blot densities are expressed as fold change compared to control using ImageJ (https://imagej.net) online software (C). Data are mean $\pm S D(n=3)$. $* p<0.05$ vs control.

Abbreviation: NF- $\mathrm{KB}$, nuclear factor-kappa B.
According to CSC concept, subpopulation of CSCs confers chemotherapy resistance. Numerous dietary compounds, comprising koenimbin, ${ }^{7}$ curcumin ${ }^{53,54}$ sulforaphane, ${ }^{55}$ and synthetic compounds including monobenzyltin Schiff base complex, ${ }^{56,57}$ revealed the chemopreventive properties toward CSCs. In this study, the anticancer activity of koenimbin against human PCSCs was examined in vitro to manifest the chemopreventive activity of koenimbin and the implications of the CSC concept. However, there is a limitation for the current study to undertake a clinical trial of koenimbin in prostate cancer patients.

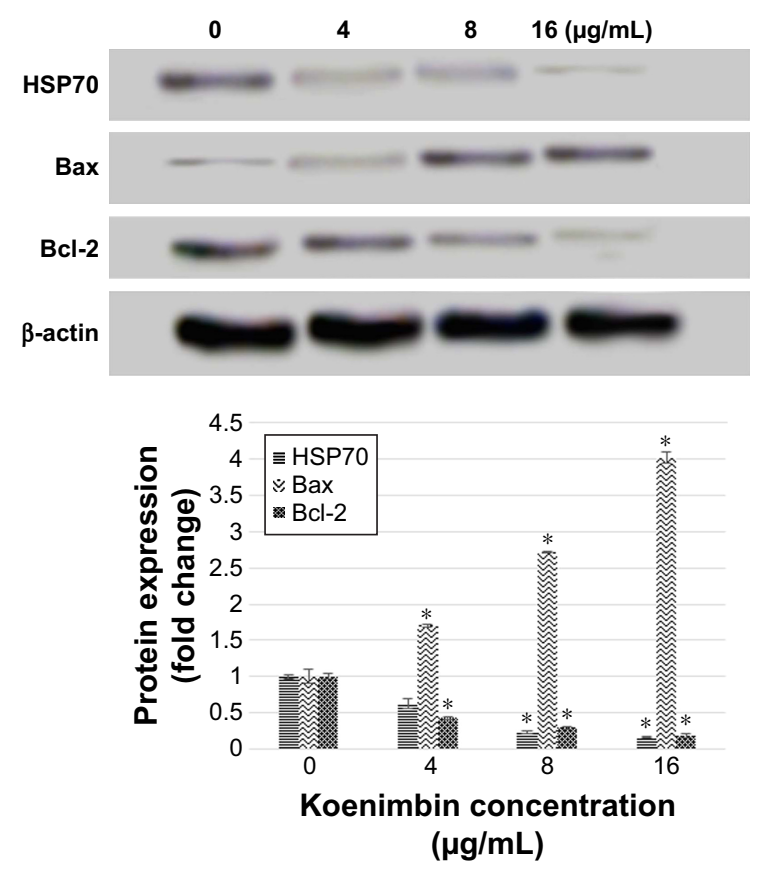

Figure 13 The expression of selected apoptotic-related proteins including $\mathrm{Bcl}-2$, Bax, and HSP70 using Western blotting method. Note: Data are mean $\pm S D(n=3) . * P<0.05$ vs control. 
Methods including prostasphere formation, CD markers, and Aldefluor enzymatic assay are used for isolation and identification of PCSCs in vitro. Isolation and expansion of prostate stem/progenitor cells $\mathrm{s}^{7,58,59}$ using nonadherent prostasphere formation assay rely on the collapse of differentiated cells to survive and proliferate in serum-free suspension compared to stem/progenitor cells. ${ }^{60}$ Corroborating with earlier evidences $^{7,61}$ that prostaspheres are formed principally of CSCs, our results demonstrated that koenimbin significantly repressed the formation of prostate stem cell prostaspheres, suggesting that koenimbin has the capability to target PCSCs derived from PC-3 cells in vitro. The important avenue for comparing between prostate stem/progenitor cells and differentiated cancer cells encompasses the employment of cell markers and ALDH enzyme activity. ${ }^{7}$

ALDH is significantly expressed in numerous different tumors comprising brain, breast, colon, liver, lung, and pancreatic cancers. ${ }^{62}$ ALDH-positive cells from CSCs demonstrated the effective potential for tumor-initiating cells with increased multiplication rate, metastasis, and adhesion capability. In this study, koenimbin revealed not only rupturing of the prostaspheres from ALDH-positive PC-3 cells but also the reduction in the expression of stem cell CD44+/CD133 markers. Consistent with previous studies, our study shows that koenimbin is able to selectively suppress human breast CSCs in mammosphere formation assay and Aldefluor assay, demonstrating the important potential role of koenimbin to target CSCs. ${ }^{7}$

\section{Conclusion}

Koenimbin has the capability to induce apoptosis in human androgen-independent PC-3 cells in vitro through the intrinsic signaling pathway and suppression of translocation of cytoplasmic NF- $\mathrm{KB}$ into the nucleus. In addition, koenimbin has the effective potential to target PCSCs as affirmed by the prostasphere formation assay and Aldefluor assay. Our study outcomes may assist the search for better cancer therapy approaches via the molecular apoptotic mechanisms through which koenimbin exerts its effects on prostate cancer cells and derived PCSCs. These outcomes may result in the evolution of new chemotherapeutic approaches for the treatment of androgen-independent prostate cancer, for which there is no efficient life-prolonging treatment.

\section{Acknowledgment}

The authors would like to express their utmost appreciation to the presidency of the Islamic Republic of Iran, National Elite Foundation, for providing financial support to conduct this study.

\section{Disclosure}

The authors report no conflicts of interest in this work.

\section{References}

1. Vineis P, Wild CP. Global cancer patterns: causes and prevention. Lancet. 2014;383(9916):549-557.

2. Sartor O, Coleman R, Nilsson S, et al. Effect of radium-223 dichloride on symptomatic skeletal events in patients with castration-resistant prostate cancer and bone metastases: results from a phase 3, doubleblind, randomised trial. Lancet Oncol. 2014;15(7):738-746.

3. Schrecengost R, Knudsen KE. Molecular pathogenesis and progression of prostate cancer. Semin Oncol. 2013;40(3):244-258.

4. Fiñones RR, Yeargin J, Lee M, et al. Early human prostate adenocarcinomas harbor androgen-independent cancer cells. PLoS One. 2013; 8(9): 74438.

5. Santos J, Teixeira A, Dias F, et al. Restoring TGF $\beta 1$ pathway-related microRNAs: possible impact in metastatic prostate cancer development. Tumor Biol. 2014;35(7):6245-6253.

6. Foo JB, Saiful Yazan L, Tor YS, et al. Induction of cell cycle arrest and apoptosis by betulinic acid-rich fraction from Dillenia suffruticosa root in MCF-7 cells involved p53/p21 and mitochondrial signalling pathway. J Ethnopharmacol. 2015;166(0):270-278.

7. Ahmadipour F, Noordin MI, Mohan S, et al. Koenimbin, a natural dietary compound of Murraya koenigii (L) Spreng: inhibition of MCF7 breast cancer cells and targeting of derived MCF7 breast cancer stem cells (CD44+/CD24-/low): an in vitro study. Drug Des Devel Ther. 2015;9:1193.

8. Yadav S, Vats V, Dhunnoo Y, Grover J. Hypoglycemic and antihyperglycemic activity of Murraya koenigii leaves in diabetic rats. J Ethnopharmacol. 2002;82(2-3):111-116.

9. Nakamura S, Nakashima S, Oda Y, et al. Alkaloids from Sri Lankan curry-leaf (Murraya koenigii) display melanogenesis inhibitory activity: structures of karapinchamines A and B. Bioorg Med Chem. 2013;21(5):1043-1049.

10. Liu H, Schmitz JC, Wei J, et al. Clove extract inhibits tumor growth and promotes cell cycle arrest and apoptosis. Oncol Res. 2014;21(5):247.

11. Piao S, Kang M, Lee YJ, et al. Cytotoxic effects of escin on human castration-resistant prostate cancer cells through the induction of apoptosis and G2/M Cell cycle arrest. Urology. 2014;84(4): 982.e981-982.e987.

12. Hsu A, Bruno RS, Löhr CV, et al. Dietary soy and tea mitigate chronic inflammation and prostate cancer via NFKB pathway in the Noble rat model. J Nutr Biochem. 2011;22(5):502-510.

13. Kiliccioglu I, Konac E, Varol N, Gurocak S, Bilen CY. Apoptotic effects of proteasome and histone deacetylase inhibitors in prostate cancer cell lines. Genet Mol Res. 2014;13(2):3721.

14. Kamalidehghan B, Houshmand M, Kamalidehghan F, et al. Establishment and characterization of two human breast carcinoma cell lines by spontaneous immortalization: discordance between estrogen, progesterone and HER2/neu receptors of breast carcinoma tissues with derived cell lines. Cancer Cell Int. 2012;12(1):43.

15. Wu C-H, Hong B-H, Ho C-T, Yen G-C. Targeting cancer stem cells in breast cancer: potential anticancer properties of 6-shogaol and pterostilbene. J Agric Food Chem. 2015;63(9):2432-2441.

16. Tabarestani S, Ghafouri-Fard S. Cancer stem cells and response to therapy. Asian Pac J Cancer Prev. 2012;13(12):5947-5954.

17. Wang A, Chen L, Li C, Zhu Y. Heterogeneity in cancer stem cells. Cancer Lett. 2015;357(1):63-68.

18. Ffrench B, Gasch C, O’Leary JJ, Gallagher MF. Developing ovarian cancer stem cell models: laying the pipeline from discovery to clinical intervention. Mol Cancer. 2014;13(1):262.

19. Deng Z, Wu Y, Ma W, Zhang S, Zhang Y-Q. Adoptive T-cell therapy of prostate cancer targeting the cancer stem cell antigen EpCAM. BMC Immunol. 2015;16:1.

20. Zuo J, Guo Y, Peng X, et al. Inhibitory action of pristimerin on hypoxiamediated metastasis involves stem cell characteristics and EMT in PC-3 prostate cancer cells. Oncol Rep. 2015;33(3):1388-1394. 
21. Zi X, Guo Y, Simoneau AR, et al. Expression of Frzb/secreted Frizzledrelated protein 3, a secreted Wnt antagonist, in human androgenindependent prostate cancer PC-3 cells suppresses tumor growth and cellular invasiveness. Cancer Res. 2005;65(21):9762-9770.

22. Singh PR, Priya ES, Balakrishnan $S$, et al. Inhibition of cell survival and proliferation by nimbolide in human androgen-independent prostate cancer (PC-3) cells: involvement of the PI3K/Akt pathway. Mol Cell Biochem. 2017:427(1-2):69-79.

23. Yamazaki H, Schneider E, Myers CE, Sinha BK. Oncogene overexpression and de novo drug-resistance in human prostate cancer cells. Biochim Biophys Acta. 1994;1226(1):89-96.

24. Huang I-P, Sun S-P, Cheng S-H, et al. Enhanced chemotherapy of cancer using $\mathrm{pH}$-sensitive mesoporous silica nanoparticles to antagonize P-glycoprotein-mediated drug resistance. Mol Cancer Ther. 2011; 10(5):761-769.

25. Tachibana Y, Kikuzaki H, Lajis NH, Nakatani N. Antioxidative activity of carbazoles from Murraya koenigii leaves. J Agric Food Chem. 2001;49(11):5589-5594.

26. Maitland NJ, Collins AT. Prostate cancer stem cells: a new target for therapy. J Clin Oncol. 2008;26(17):2862-2870.

27. Bank HL. Rapid assessment of islet viability with acridine orange and propidium iodide. In Vitro Cell Dev Biol. 1988;24(4):266-273.

28. Ibrahim MY, Hashim NM, Mohan S, et al. $\alpha$-Mangostin from Cratoxylum arborescens demonstrates apoptogenesis in MCF-7 with regulation of $\mathrm{NF}-\mathrm{KB}$ and $\mathrm{Hsp} 70$ protein modulation in vitro, and tumor reduction in vivo. Drug Des Devel Ther. 2014;8:1629.

29. Jung EB, Lee CS. Baicalein attenuates proteasome inhibition-induced apoptosis by suppressing the activation of the mitochondrial pathway and the caspase-8- and Bid-dependent pathways. Eur J Pharmacol. 2014;730(0):116-124.

30. Alfredsson CF, Ding M, Liang Q-L, Sundström BE, Nånberg E. Ellagic acid induces a dose- and time-dependent depolarization of mitochondria and activation of caspase-9 and -3 in human neuroblastoma cells. Biomed Pharmacother. 2014;68(1):129-135.

31. Lee S-T, Wong P-F, Cheah S-C, Mustafa MR. Alpha-tomatine induces apoptosis and inhibits nuclear factor-kappa B activation on human prostatic adenocarcinoma PC-3 Cells. PLoS One. 2011;6(4):e18915.

32. Lee S-T, Wong P-F, Hooper JD, Mustafa MR. Alpha-tomatine synergises with paclitaxel to enhance apoptosis of androgen-independent human prostate cancer PC-3 cells in vitro and in vivo. Phytomedicine. 2013;20(14):1297-1305.

33. Tang Y, Chen R, Huang Y, et al. Natural compound alternol induces oxidative stress-dependent apoptotic cell death preferentially in prostate cancer cells. Mol Cancer Ther. 2014;13(6):1526-1536.

34. Makowska K, Estañ MC, Gañán-Gómez I, Boyano-Adánez MC, García-Pérez AI, Sancho P. Changes in mitochondrial function induced by dequalinium precede oxidative stress and apoptosis in the human prostate-cancer cell line PC-3. Mol Biol. 2014;48(3): 359-370.

35. Damla Arisan E, Obakan P, Coker-Gurkan A, Calcabrini A, Agostinelli E, Palavan Unsal N. CDK inhibitors induce mitochondria-mediated apoptosis through the activation of polyamine catabolic pathway in LNCaP, DU145 and PC3 prostate cancer cells. Curr Pharm Design. 2014;20(2):180-188.

36. Shen T, Zhang L, Wang Y-Y, et al. Steroids from Commiphora mukul display antiproliferative effect against human prostate cancer PC3 cells via induction of apoptosis. Bioorg Med Chem Lett. 2012; 22(14):4801-4806.

37. Bishayee K, Chakraborty D, Ghosh S, Boujedaini N, Khuda-Bukhsh AR. Lycopodine triggers apoptosis by modulating 5-lipoxygenase, and depolarizing mitochondrial membrane potential in androgen sensitive and refractory prostate cancer cells without modulating p53 activity: Signaling cascade and drug-DNA interaction. Eur J Pharmacol. 2013; 698(1-3):110-121.

38. Kim K-Y, Yu S-N, Lee S-Y, et al. Salinomycin-induced apoptosis of human prostate cancer cells due to accumulated reactive oxygen species and mitochondrial membrane depolarization. Biochem Biophys Res Commun. 2011;413(1):80-86.
39. Kao Y-L, Kuo Y-M, Lee Y-R, Yang S-F, Chen W-R, Lee H-J. Apple polyphenol induces cell apoptosis, cell cycle arrest at G2/M phase, and mitotic catastrophe in human bladder transitional carcinoma cells. J Func Foods. 2015;14(0):384-394.

40. Shoja MH, Reddy ND, Nayak PG, Srinivasan KK, Rao CM. Glycosmis pentaphylla (Retz.) DC arrests cell cycle and induces apoptosis via caspase-3/7 activation in breast cancer cells. J Ethnopharmacol. 2015; 168(0):50-60.

41. Saleh AM, El-Abadelah MM, Aziz MA, Taha MO, Nasr A, Rizvi SAA. Antiproliferative activity of the isoindigo $5^{\prime}-\mathrm{Br}$ in HL-60 cells is mediated by apoptosis, dysregulation of mitochondrial functions and arresting cell cycle at G0/G1 phase. Cancer Lett. 2015;361(2): 251-261.

42. Yang L, Zhou Y, Li Y, et al. Mutations of $\mathrm{p} 53$ and KRAS activate NF- $\mathrm{kB}$ to promote chemoresistance and tumorigenesis via dysregulation of cell cycle and suppression of apoptosis in lung cancer cells. Cancer Lett. 2015;357(2):520-526.

43. Arbab IA, Abdul AB, Hassan BA, Beelly OBI. Dentatin induces apoptosis in $\mathrm{PC} 3$ and $\mathrm{LNCaP}$ prostate cancer cells via $\mathrm{Bcl}-2, \mathrm{Bcl}-\mathrm{xL}$, survivin downregulation, caspase- $9,-3 / 7$ activation, and NF- $\mathrm{\kappa B}$ inhibition. Asian Pacific J Trop Dis. 2014;4(3):230.

44. Lu L, Tang D, Wang L, et al. Gambogic acid inhibits TNF-[alpha]induced invasion of human prostate cancer $\mathrm{PC} 3$ cells in vitro through PI3K/Akt and NF-[kappa]B signaling pathways. Acta Pharmacol Sin. 2012;33(4):531-541.

45. Thapa D, Meng P, Bedolla RG, Reddick RL, Kumar AP, Ghosh R. NQO1 suppresses NF- $\mathrm{KB}-\mathrm{p} 300$ interaction to regulate inflammatory mediators associated with prostate tumorigenesis. Cancer Res. 2014; 74(19):5644-5655.

46. Nguyen DP, Li J, Yadav SS, Tewari AK. Recent insights into NF-кB signalling pathways and the link between inflammation and prostate cancer. BJU Int. 2014;114(2):168-176.

47. Gil-Araujo B, Toledo Lobo M-V, Gutiérrez-Salmerón M, et al. Dual specificity phosphatase 1 expression inversely correlates with NF- $\mathrm{KB}$ activity and expression in prostate cancer and promotes apoptosis through a p38 MAPK dependent mechanism. Mol Oncol. 2014; $8(1): 27-38$.

48. Deeb D, Gao X, Dulchavsky SA, Gautam SC. CDDO-me induces apoptosis and inhibits Akt, mTOR and NF- $\mathrm{KB}$ signaling proteins in prostate cancer cells. Anticancer Res. 2007;27(5A): 3035-3044.

49. Babaei MA, Huri HZ, Kamalidehghan B, Yeap SK, Ahmadipour F. Apoptotic induction and inhibition of $\mathrm{nF}-\mathrm{\kappa B}$ signaling pathway in human prostatic cancer Pc3 cells by natural compound 2, 2'-oxybis (4-allyl-1-methoxybenzene), biseugenol B, from Litsea costalis: an in vitro study. OncoTargets Ther. 2017;10:277.

50. Mohan S, Abdelwahab SI, Kamalidehghan B, et al. Involvement of $\mathrm{NF}-\mathrm{\kappa B}$ and $\mathrm{Bcl}$ /Bax signaling pathways in the apoptosis of MCF7 cells induced by a xanthone compound pyranocycloartobiloxanthone A. Phytomedicine. 2012;19(11):1007-1015.

51. Ibrahim MY, Hashim NM, Mohan S, et al. Involvement of $\mathrm{nF}-\mathrm{\kappa B}$ and hsP70 signaling pathways in the apoptosis of MDa-MB-231 cells induced by a prenylated xanthone compound, $\alpha$-mangostin, from Cratoxylum arborescens. Drug Des Devel Ther. 2014;8:2193.

52. Mosser DD, Caron AW, Bourget L, et al. The chaperone function of hsp70 is required for protection against stress-induced apoptosis. Mol Cell Biol. 2000;20(19):7146-7159.

53. Wang Z, Zhang Y, Banerjee S, Li Y, Sarkar FH. Notch-1 downregulation by curcumin is associated with the inhibition of cell growth and the induction of apoptosis in pancreatic cancer cells. Cancer. 2006; 106(11):2503-2513.

54. Jaiswal AS, Marlow BP, Gupta N, Narayan S. [beta]-Catenin-mediated transactivation and cell-cell adhesion pathways are important in curcumin (diferuylmethane)-induced growth arrest and apoptosis in colon cancer cells. Oncogene. 2002;21(55):8414.

55. Li Y, Zhang T, Korkaya H, et al. Sulforaphane, a dietary component of broccoli/broccoli sprouts, inhibits breast cancer stem cells. Clin Cancer Res. 2010;16(9):2580-2590. 
56. Fani S, Kamalidehghan B, Lo KM, et al. Anticancer activity of a monobenzyltin complex C1 against MDA-MB-231 cells through induction of apoptosis and inhibition of breast cancer stem cells. Sci Rep. 2016;6:38992.

57. Fani S, Dehghan F, Karimian H, et al. Monobenzyltin complex C1 induces apoptosis in MCF-7 breast cancer cells through the intrinsic signaling pathway and through the targeting of MCF-7-derived breast cancer stem cells via the $\mathrm{Wnt} / \beta$-catenin signaling pathway. PLoS One. 2016;11(8):e0160836.

58. Chen X, Rycaj K, Liu X, Tang DG. New insights into prostate cancer stem cells. Cell Cycle. 2013;12(4):579-586.

59. El-Merahbi R, Liu Y-N, Eid A, et al. Berberis libanotica Ehrenb extract shows anti-neoplastic effects on prostate cancer stem/progenitor cells. PLoS One. 2014;9(11):e112453.
60. Zhou J, Wang H, Cannon V, Wolcott KM, Song H, Yates C. Side population rather than CD133 (+) cells distinguishes enriched tumorigenicity in hTERT-immortalized primary prostate cancer cells. Mol Cancer. 2011;10(112):763-768.

61. Abou-Kheir W, Hynes PG, Martin P, et al. Self-renewing Pten-/TP53 -/- protospheres produce metastatic adenocarcinoma cell lines with multipotent progenitor activity. PLoS One. 2011;6(10):e26112.

62. Hellsten R, Johansson M, Dahlman A, Sterner O, Bjartell A. Galiellalactone inhibits stem cell-like ALDH-positive prostate cancer cells PLoS One. 2011;6(7):e22118.

\section{Publish your work in this journal}

Drug Design, Development and Therapy is an international, peerreviewed open-access journal that spans the spectrum of drug design and development through to clinical applications. Clinical outcomes, patient safety, and programs for the development and effective, safe, and sustained use of medicines are the features of the journal, which has also been accepted for indexing on PubMed Central. The manuscript management system is completely online and includes a very quick and fair peer-review system, which is all easy to use. Visit http://www.dovepress.com/testimonials.php to read real quotes from published authors.

Submit your manuscript here: http://www.dovepress.com/drug-design-development-and-therapy-journal 